\title{
Design and Development of Corrosion Resistance Coating for Pipes in Fire Protection Sprinkler Systems : A Review Jitendra Jangid,
} Manipal University of Higher Education, Dubai

\begin{abstract}
Article Info
Volume 8 Issue 1

Page Number: 87-104

Publication Issue :

January-February-2021
\end{abstract}

\section{Article History}

Accepted : 01 Jan 2021

Published : 25 Jan 2021

\section{ABSTRACT}

Fire pumping systems are often used in most buildings for firefighting, whether they are residential, commercial, industrial or of any other kind. Such systems are responsible for the water flow and pressure necessary for manual or automatic devices designed to build safety. Therefore, ensuring their availability when an unexpected fire event occurs is very critical. But due to the presence of dissolved oxygen in the water-filled in the pipes, corrosion takes place at some point in time. This will lead to several types of failures in the system if the system is not properly designed with the right material for the environmental conditions and water quality, which in turn will render the system ineffective. This paper discusses the reasons for corrosion in the piping of fire sprinkler systems and their mitigation.

Keywords : Corrosion, Fire Protection, Piping, Sprinkler, Galvanized steel, copper, MIC

\section{INTRODUCTION}

Fire protection is the study and practice of mitigating the unwanted effects of potentially destructive fires in domestic and industrial environments [1].

In the current market, both manual and automatic fire fighting techniques are available. Manual systems for fire protection include the use of fire extinguishers and fire blanket. Fire blanket is nothing but a sheet of fire-retardant material that can be placed on a fire to halt it. They are generally made of fibre glass or from Kevlar. The other common way is to use a fire extinguisher, which are easy to use.

Ever since the harmful effects of Halon 1301 (which was earlier used in fire suppression system) in depleting the ozone layer were found out, the development and synthesis of an alternative nonozone depleting agent has attracted many international research interests and, as a revolution in fire suppression technology, aerosol fire extinguishing agent is developed from pyrotechnics, a safe and practical alternative to halons, halocarbons, chemical powders and inert gases [2]. Dry chemical compounds are commonly used in fire extinguishing devices. These compositions comprise a pulverized, dry, solid fire extinguishing material. A propellant gas is employed in a standard dry chemical fire extinguisher to convey the composition selectively [3]. Now a days, the fire extinguishers usually contain pressurized $\mathrm{CO}_{2}$ or Nitrogen.

Copyright : (C) the author(s), publisher and licensee Technoscience Academy. This is an open-access article distributed under the terms of the Creative Commons Attribution Non-Commercial License, which permits unrestricted noncommercial use, distribution, and reproduction in any medium, provided the original work is properly cited 
The automatic fire fighting systems are preferred over this method as it will remove the human involvement in the process, making it safer during the fire events. Sprinkler systems, Gaseous clean agents and Foam suppression systems are used for mitigating fire with no or very less involvement of humans. The sprinkler systems are the most common ones, but in places like server rooms and computer rooms, where water sprinkler systems will do more harm than good, the gaseous clean agents must be used. A foam fire suppression system is the one that has a source of water, a source of foam agent, and a pump with an inlet and a discharge. Where the source of water is combined with the source of the foam agent, before reaching the pump inlet [4].

Conventionally, fire protection sprinklers are attached to a pipe to collect pressurized fire extinguishing gas, such as water [5]. Usually, a fire sprinkler system's component includes a set of vertical and horizontal supply pipes connected by threaded, grooved or glued fittings, and braced against gravity loads [6].

With increased urbanization and complex infrastructure development such as advanced warehouses, mines, power distribution centers, refineries, multi-story residential and commercial buildings, etc., it is necessary to have a good piping network to provide sufficient quantities of clean water to tackle fire hazards. [7].

Once the detector / alarm / operator receives a signal, the pump starts to work automatically and takes out water from the tank and sprays into the fire zone [8]. If the spray path is not activated, local operators can manually switch on the spray path, and if the manual path is not available, the operators can request assistance from the local fire station, although the detector can be designed to send a signal directly to the fire department automatically.
Fire retardants limit material flammability by either actively stopping the fire or triggering a chemical reaction that stops the fire [9]. A lot of such fireretardant products are now available in the current market, though few such products are water - soluble and non - toxic.

In the fire protection system, corrosion reduction becomes important which adds to the costs of the system. The other option is choosing the corrosionresistant materials, which are expensive, which results in very high initial costs [10]. Then there is a possibility of using coatings or cathodic protection, which also results in additional costs.

In buildings that have fire protection sprinkler systems, the sprinkler system handles detection, location and suppression / control [11]. A modern, working sprinkler device can monitor or extinguish a fire until it bursts over a room. Nevertheless, that is not the case with the un-sprinklered houses, where smoke and heat are emitted with large amounts by the time the fire brigade appears, and most of the building can only begin to evacuate.

Fire protection sprinkler systems are widely used when sensing heat or smoke, to prevent fires with water. These systems typically include a water source such as a city water tank, one or more sprinklers such as heat-activated fusible sprinkler heads, and a piping network that links the water source and the sprinkler heads [12].

The thermally responsive element (which extends through the tune of the sprinkler between the nozzle and the inlet end for maintaining a seal at the inlet end) is configured to lose structural integrity under the predetermined thermodynamic condition and thus allow the mobile member to move from a position of pre-activation to an activated position generally close to the base [13] [14]. 
Firefighting sprinkler systems aimed at protecting commercial and non-commercial multi-floor properties have a wet standpipe that usually extends upwards through the property floors and a huge multi-valve manifold assembly that branches off the standpipe at each floor [15].

Water-based fire sprinkler systems are widely used against fire to protect houses, properties and people. The fire protection sprinkler systems are mainly of three types, wet pipe systems, dry pipe systems, and deluge system [16]. The two primary forms of fire sprinkler systems are focused on water, wet pipe sprinkler systems and dry pipe sprinkler systems [17].

In wet pipe sprinkler systems, until the system is actuated with sensors, the piping network remains filled with water. A Wet Pipe Sprinkler System is defined as a sprinkler system by means of automatic sprinklers mounted on a water-containing pipe system and connected to a water supply system. When the automatic sprinkler is actuated in response to a fire, the water is immediately discharged at a minimum designed, working or operating pressure to deal with the fire [18]. The water may freeze when exposed to freezing temperatures causing the piping network to burst, which results in substantial property damage and rendering the system inoperable [19]. Therefore, it is not advisable to use wet pipe sprinkler systems for applications involving freezing temperatures. But, now even anti-freeze solutions are available which can be added to the water for such environments [20].

When the tank is emptied for repairs or in the case of a fire crash and flooded with water again, air vents must be removed to allow air or other gas to escape through the water (2016 NFPA 13).

These air vents are installed at high points in the piping network and include a mechanism, such as a poppet or ball valve, ideally enabling air to escape but blocking the flow of water from the air [21].
The dry sprinkler system comprises an inlet end enclosure, an outlet end, a fluid flow path from the inlet end to the outlet end and a main longitudinal line around the fluid flow path [22].

Corrosion of pipes, fittings and fasteners can result in premature replacement of these components, and in the worst case can cause structural failure for the system [23]. To combat this, pipes and fittings are generally galvanized to resist corrosion of the steel substrate, and fasteners are formed from stainless steel materials. However, galvanizing, as it is not $100 \%$ effective, does not provide the desired long life for pipes and fittings, while stainless steel is expensive [23].

Many people in the fire-fighting industry have learned about the corrosion in a hard way, not getting any formal training in the science of corrosion but often having to deal with it out of necessity. Many know a great deal about corrosion but very little about fire sprinkler systems. New and innovative approaches are designed to slow down corrosion, prolong component life and have the system ready for firefighting when needed, while others are produced to mitigate the effects of leaks, etc.

In Fire Sprinkler systems, corrosion phenomenon was well documented. The most common corrosion reaction seen in fire sprinkler systems is by far oxidation. Oxygen trapped inside the system dissolves into water and reacts to the inner surface by piping copper or black or galvanized steel. This reaction produces iron oxide debris that ultimately leads to major problems such as obstruction of the Sprinkler pipe, Sprinkler plugging, reduced hydraulic performance, Pinhole leaks, short service life, repair costs, property damage, business disruption.

There are various types of corrosion, such as:

- General or uniform corrosion

- Galvanic corrosion

- Crevice corrosion 
- Pitting (pinholes)

- Selective leaching

- Intergranular corrosion (weld decay)

- Microbiologically influenced corrosion

- Environmental cracking, including Fretting (fatigue)

- Erosion corrosion

While most of the time, corrosion is caused by metal oxidation, but another important cause is microbiologically induced corrosion (MIC), or corrosion caused by the growth of micro-organisms in the inner surface of the tubes like bacteria, microalgae, and fungi. That's a different cause than galvanic or oxygen corrosion, but the effects can be just as disastrous: leakage of the pinhole, obstructions, sludge, tubercles and rusting and condensation of the surface. Unfortunately, building owners and property managers continue to lack a general knowledge about deterioration of fire sprinkler systems by corrosion.

Generally, the materials and their associated degradation, evaluating the repair and maintenance expense, were evaluated about corrosion. There is often a common viewpoint from the standpoint of environmental management where the degradation is known to be a cause of dissolved material incorporated into the water. [24].

Physical corrosion of the metal can occur in any corrosive environment in the following two different ways:

i. General metal thinning over wide areas, causing the wall thickness to be gradually lost.

ii. Pitting attack leading to highly localized metal loss at certain points at the pipe 's surface.

Pitting attack is especially troubling since it can result in premature failures on an otherwise moderately weakened area in the pipe wall. Owing to dispersed degradation in a fire sprinkler device, a significant number of leaks occur.

\section{Fire sprinkler piping materials}

The fire sprinkler has grown and changed over the years, as has the piping device that has protected it since its invention in 1864. The first piping of the fire sprinkler was black iron, replaced in 1892 by steel piping. The copper tube entered the fire sprinkler market in the 1960s, the CPVC (chlorinated polyvinyl chloride), PB (polybutylene) and these light well steel sprinkler pipes were used in fire sprinkler systems during the 1980s. Since the advent of these tube materials the construction of fire sprinkler systems has increased.

In principle, the word "pipe" is used for steel and iron ductile products, while the word "tube" is used for copper [25]. The difference in production method of these two products depends on how the term "pipe" and "tube" technically differs.

The steel, copper, CPVC and PB sprinkler pipe has different material properties such as the temperature of the melting point or heat distortion, linear expansion coefficient and weight per unit volume. The steel fire sprinkler pipe has always been an irreplaceable material for use in the construction industry, owing to its economic benefit and high mechanical strength. The type of pipe used in the system can be recognized by appearance and marking when inspecting an installed fire sprinkler device.

\subsection{Steel:}

A normal carbon steel pipe is used to convey fire suppressants such as water or gas. This is usually red. But light-wall pipes have a silvery-looking galvanized exterior. Red steel pipe installation is confined to wet pipe sprinkler systems only. The melting point of the steel used in the fire sprinkler system is from $1427^{\circ} \mathrm{C}$ 
to $1538{ }^{\circ} \mathrm{C}$. Steel sprinkler pipe has a pressure rating of $1.21 \mathrm{Mpa}$. The standard specifications for all the variations of the steel can be found in the latest copy of the NFPA 13 publication.

Spontaneous iron - water corrosion is susceptible to low-carbon steel pipe. "The primary cause of internal corrosion (metal loss) in fire sprinkler systems is oxygen attack of the iron and zinc (in the case of galvanized pipe) that are used to fabricate fire sprinkler system piping" [26]. The FPS pipes never drain completely, and the residual water that remains creates ideal conditions for the corrosion initiation and propagation through galvanic or biological induced corrosion in the piping [27]. Electrochemical reactions between iron, humidity and air oxygen cause rust spoilage. Moreover, certain dissolved chemical substances change the water into an electrolyte, which is a conducting medium electrically. As proved by Cicek [28], "Waterline corrosion occurs due to the difference of oxygen concentrations close to the water surface and below". But constant non-porous, adhesive surface laminating can avoid touching the iron metal of the internal pipe wall with corrosive chemical species in water. For example, in the galvanizing processes, such as heat dipping, the zinc metal surface coating serves as a sacrificial material, which corrodes the underlying iron metals preferentially.

"Liquid water is a necessary component for corrosion to occur, wherein a molecule of the metal at the wetted surface gives up an electron(s) to an oxidizing constituent in the water and the metal becomes a water-soluble ion. The net effect of this chemical reaction is that a void is created at the point where the metal molecule was liberated from the substrate metal surface. A pit is formed. As the process continues, the metal degrades and eventually a failure occurs" [29].

The process of corrosion even happens in galvanized steel. "Under persistently moist, oxygenated conditions, galvanized steel will corrode aggressively. This occurs because the protective zinc carbonate coating is not stable if the surface remains moist" [30]. Under such conditions, the zinc layer will continue to be dissolved and the underlying steel will be exposed to an aggressive, highly localized oxygen attack at the point when the zinc layer is initially breached. Also, according to Bruce [31],

"These and other surface coatings are likely to be scraped away during piping system fabrication processes such as threading and cut grooving, and sawing and drilling." In the case of oxygenated acid solutions, acid - oxygen corrosion takes place when hydrogen ions and dissolved oxygen act together to extract electrons from iron metal. While not fully understood electrochemical specifications, intensified corrosion is likely to occur as the dissolved oxygen reacts in conjunction with iron hydrogen ions (II) and iron deficient in electron (III), which quickly extracts electrons from iron-metal to make more iron (II)[32].

This cyclic iron metal corrosion occurs more quickly than the corrosive effects of dissolved oxygen or hydrogen ions, which alone react with iron metal [32].

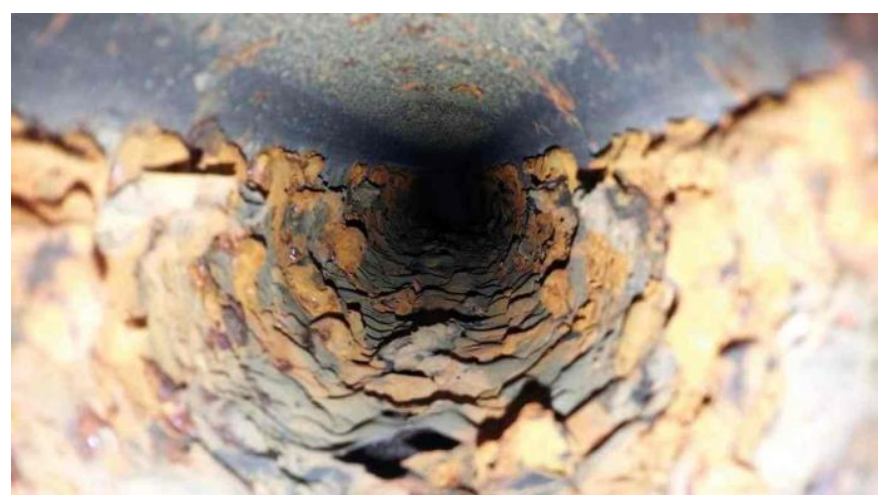

Figure 1: Severe corrosion inside steel pipe of a wet type fire sprinkler system (image by IFP: The problem of corrosion in metal fire sprinkler system 2017

Spontaneous metal-water corrosion-reactions can change the electrochemical voltage due to external electrical factors sometimes unwittingly imposed on 
metal-water system. A adequate positive DC voltage will speed metal - water corrosion and a sufficient negative DC voltage will delay corrosion [31]. If the piping device is electrically grounded, external electrical influences are unlikely to play a part in the corrosion of hot-water hot sprinklers [31].

In all areas of exposed surface coatings, corrosive waters may attack bare iron. The reclaim of a damaged area, possibly with a non-reaction polymer, will minimize exposure to corrosive water of iron metal. "NFPA 13 implicitly addresses the following internal corruption:" The thickness of the wall shall be in accordance with Schedule 30[in size 8 in the case where the supplies of water have unusual corrosive properties and threaded or cut-grow steel pipes should be used. Or Schedule 40 \{less than 8 in. $(200 \mathrm{~mm})\}$ or larger [33]. Sometimes the pipes and the fittings have different material, for example - a black steel pipe coupled with a bronze fitting, this will give rise to the corrosion phenomenon as "it will be apparent that two corrosion mechanisms are in place when the piping System is placed in service by filling it with water under pressure. These two mechanisms are: (1) the introduction of an electrolyte (water) that by its very nature is corrosive when in contact with ferrous-based materials and (2) activation of the classic dissimilar metals galvanic couple" [34], black steel and bronze in this case.

Every time the water in the system is changed, it recharges the system gets a supply of fresh oxygen and this will result in removal of more metal from the walls of the pipes. "Any deposits that exist on the metal surfaces will create oxygen concentration cells in the fresh oxygen rich water and the otherwise low general rate of corrosion will be greatly accelerated and pitting attack of the pipe wall will occur" [26].

Also, the MIC, a type of micro-organism biodeterioration, that will devastatingly affect the functionality and durability of buried installations
[35]. Many of the more common types involve bacteria that lower sulphur content, metal reduction bacteria, acid-producing MIC products, bacteria that deposit iron, low-nutrient bacteria, iron-reduction bacteria, bacteria that decrease iron oxide, sulphate oxidizing bacteria, slimming bacteria and iron bacteria [36]. In the corrosion process for iron alloys, the key symptom usually refers to localized corrosion filling with black sulphide corrosion products [37]. The MIC is due to the interaction that is synergetic between the bacteria and the metal surface [38]. Micro-organisms' intrinsic behaviour is to colonize in many environments on a solid surface. A community of anaerobic bacteria is Sulphate-Reducing bacteria (SRB) [39] in a geothermally active environment still present under extreme conditions like the underground mine [40]. In general, there is evidence that mackinawite and greigite have participated in the corrosion reaction in iron corrosion products [39]

The involvement of iron corrosion products of mackinawite and greigite typically indicates that SRB has taken part in the corrosion reaction. Specific forms of bacteria play a significant role in the control of MIC, which may be classed as either aerobic or anaerobic. Aerobic bacteria are organisms that need oxygen, whereas anaerobic bacteria are not active [41].

MIC removes material through a series of electrochemical interactions, as with other forms of corrosion. The MIC produces an electrical as well as a chemical component [42]. Amongst the different possible mechanisms of corrosion phenomenon, the microbiologically induced/influenced corrosion (MIC), this is caused by live micro-organisms in the piping, such as microalgae, bacteria, archaea and fungi. "The economic costs associated with microbiologically influenced corrosion in buried pipelines in oil, gas, petrochemical industries, power plants, and other chemical plants are enormous" [35]. Microbial corrosion of steel, with the latter considered to cause a higher corrosion rate, is divided 
into anaerobic and aerobic corrosions, whereas a lower corrosion rate has been identified [37]. Pinhole leakage was associated with bacteria in fire sprinkler pipe water [43].

Black steel pipe is made of non-galvanized steel. Its name derives from the scaly, dark-coloured iron oxide surface coating. It's used in applications where galvanized steel is not required. "Under persistently moist conditions with oxygen present, galvanized steel corrodes much faster than black steel and will develop leaks. Galvanized steel pipe also costs about $30 \%$ more than black steel pipe. During the process of corrosion, there is a release of $\mathrm{Zn}^{2+}$ ions by the galvanized steel pipe, into the discharge water when dry and preaction systems are tested. This results in creation of a heavy metal contamination environmental hazard" [30].

\subsection{Copper}

Copper has been used since 1961 in fire sprinkler piping, as it is a strong, durable, malleable metal. Though it has the highest initial installation costs, advocates of copper say its durability, natural corrosion resistance, and power loss prevention, meaning more water will continue to flow through the pipe, outweigh the higher initial installation price. The NFPA 13 publication can be used to get the specifications of the current standard specifications regarding the copper tubes used in the system of fire sprinklers.

The intrinsic resistance of copper to corrosion and bacterial growth minimizes scaling inside sprinkler pipes, typically allowing the maximum measurement of the inner diameter of a tube to remain constant throughout its existence and preventing MIC in the piping system which is a constant case with CPVC and Steel pipes. Although copper pipes normally corrode much slower than steel, water acidity and hardness can speed up damage levels.
A protective barrier is formed by the oxide layer that naturally forms on the inner surface of copper tubing, reduces the need for regular system flushing to avoid corrosion build-up and clogging. Its regularly smooth internal surface provides less frictional resistance than the steel pipe, giving a C-factor is 150 in case of copper. Hydraulic C-factor tests roughness on the inside of the pipes and their capacity to obstruct the flow of water. As a result, there is no need to increase material costs by over-sizing copper pipes to reduce the reduced flow capacity that can cause corrosion over time, which is often important for steel.

Within the copper fire sprinkler pipes, pitting and scale build-up can occur in time, but compared to steel pipes it occurs so gradually that it is far less of a concern. Nevertheless, water acidity and hardness can exacerbate corrosion in copper pipes and cause pinhole leaks, so it is important to ensure that water supply $\mathrm{pH}$ values remain above 7 , and water softeners are used when required. Scale forming materials just like copper show a moderate amount of corrosion leading to copper concentrations in the L-1 range of mg.

According to the experiment carried out by Sang Hee Suh and team, "There is a significant amount of pressurized air over the water in the copper tube and all the corrosion pits observed in this study were located near the water/air-line mean that the pitting corrosion was caused by the waterline corrosion"[44]. The pressure air pocket in the copper conduit over water induces pitting corrosion in it [44]. The copper pipes used in this study for the sprinkler systems consist of phosphorus de-oxidized copper with an interior diameter of $25 \mathrm{~mm}$ and a thickness of 0.89 $\mathrm{mm}$ [44]. When unloading the gas in the tube alone through the control valve or other buttons, it becomes nearly difficult to get rid of fuel. This is because there is no other choice than to stay in the tube and absorb the air immediately associated with the sprinkler mouth [44]. It has been suggested that the future material of tube applications for fire- 
fighters systems would be the carbon steel tube with a proper protective coating.
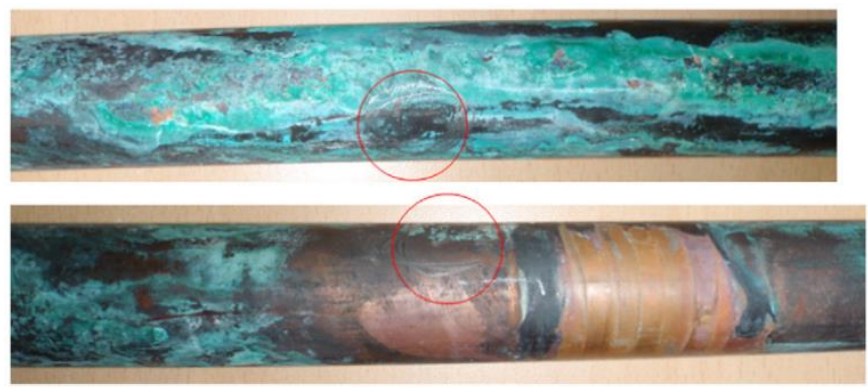

Figure 2: Corrosion failure copper tubes, red circles display water leakage locations [44]

Metallic products for tube structures may be classified according to their dimensional shaping characteristics. Copper and copper alloys, for instance, are products that shape scales, not stainless steel [45]. Copper pipe corrosion releases copper ions that can accumulate to high enough concentrations to produce solid by-products that affect their own corrosion rate [45].

There is MIC in copper pipes as well, but it affects copper in a different way than the steel pipes as confirmed by the study Dou W. and team [46], The first is known to be driven by the production of iron oxidation extracellular electrons for energy. Extracellular transfer of electrons is needed. That kind of MIC is then called the EET-MIC.

Factors that speed up corrosion rate [26]:

- Availability of fresh oxygen

- Solids such as iron oxides, dust etc.

- Contamination by microorganisms

- Mechanical deposit accumulation - byproduct of iron oxide corrosion

- Draining and refilling of the system

\section{EXPERIMENTAL PROCEDURES}

In order to assess the corrosion condition visual examination, measure of pitting depth and anodic polarization experiments are used with electrochemical potential structure. Gumbel distribution can be used to analyse the maximum pitting corrosion depth and tube lifetime prediction in extreme value statistics. High importance figures have been used for many decades to validate the pitting vulnerability. Gumbel distribution incredibly helpful and accurate statistics of severe values, not just for the calculation of maximum depth in the hole, but for the estimate of the rest of the life [47]. An electrochemical potentiodynamic polarization test is designed by its current potential relationship to characterize a metal specimen. This test is one of the proven ways to examine corrosion and passivation trends in a matter of hours [48]. The work done by Darren and Michael demonstrated that "localized or pitting corrosion can be studied at the pilot scale in reasonable time frames (e.g., several months) using a simply designed system" [49]. Copper corrosion trials, such as measurements of tubular rigs or field testing, often appear to be case studies of limited transferability to certain structures, or basic research (i.e. electrochemical experiments, coupon checks, estimates of solubility or speciation). While a certain insight can be obtained from pipeline experiments, significant improvement can only be achieved through electro-chemical experiments regarding the impact of inorganic water constituents [45].

- Visual inspection of water drained pipes: Corrosion damage can be checked lengthwise with a cut of two halves into the damaged pipe and a careful check of the internal surfaces of the pipe.

- Microscopic and structural corrosion pit analyses: Morphological details and substance compositions in the pitting corrosion region in the pipes can be collected utilizing an energy dispersion X-ray (EDS) scanning electron microscope. The XRD and micro XRD powder diffractometers have also been used to distinguish products in the pitting corrosion environment [44]. 
- Water and sediment analysis on the tube, which can be analysed through atomic absorption spectrometry (AAS). Inductively linked plasma spectrometry of optical emission (ICP-OES) and ion chromatography (IC) of the water sample collected by the sprinkler of the fire systems of the apartment complex. X-ray fluorescence spectroscopy (XRF) and Powder $\mathrm{XRD}$ have been analysed for water sediments [44].

\section{Current recommendations in mitigation of corrosion}

\subsection{Steel Pipes:}

Low carbon steel tubing is vulnerable to iron-water random corrosion. The use of a protective cover blocking iron / water corrosion reactions on the metal-water interface, if constant, adherent and nonporous, can reduce the susceptibility of any given degree. Hot dipping is the sacrificial matter which corrodes the underlying iron metal preferably [31]. Reparation for industrial processes weakened coverings may avoid bare iron access to corrosive water [31].

These and other surface layers can be scraped off during manufacturing processes of the piping system like threading, cutting, slicing and boiling. In areas where surface coverings have deteriorated, corrosive waters may attack exposed bare iron. During production processes of the pipe system, such as threading and cutting and slicing and boiling, these and other surface layers can be scraped off. Corrosive water may strike exposed bare iron in areas where surface coating has deteriorated [31].

The normal flow and cleaning of the firewater systems was suggested to avoid scale development on the inner surface [50]. In fire water piping or related tube applications the water used for drainage and washing shall not be fully drained and reused unless otherwise handled to eliminate the corrosive factor in it [50].

Black steel tube must be used in wet, dry or preaction systems for any addition, repair, replacement, relocation of existing galvanized steel tube [30]. Wet pipe Nitrogen Input (WPNI) must be included in any galvanized steel or black steel wet pipe device with corrosion-related leakage to avoid persistent corrosion [30].

A super-hydrophobic $\mathrm{PES} / \mathrm{POTS} / \mathrm{MoS}_{2}-\mathrm{PDA}-\mathrm{TiO}_{2}$ coating with high WCA of $159 \pm 2^{\circ}$ and low SA of $3 \pm$ $1^{\circ}$ is an excellent option prepared by Xiaoying Zhang and team [51] by a feasible spraying technology. The polarization curves from the test performed by the team clearly indicated that "the super-hydrophobic coating possessed high protection performance (99.982\%) and low corrosion rate $(0.262 \mu \mathrm{m} /$ year $)$ even after 15 days of immersion in a $3.5 \mathrm{wt} . \% \mathrm{NaCl}$ solution" [51]. So, it can also be an excellent option to remove corrosion from the fire sprinkler systems piping and fittings.

If water tests indicate the presence of bacteria associated with MIC, a chemical injection system must be installed to counter the bacteria from the first fill. This includes hydrostatic testing and preliminary fills [42]. There are a lot of commercial chemical injection systems available currently in the market. But again, the storage of chemical, toxicity and installation costs can be a problem here. Also, the best and foremost recommendation for preventing the MIC causing issues to the system is to thoroughly clean the interior of the piping systems. The major problem is micro-organisms, so limiting or eliminating the nutrients available for microbial consumption is the key [43]. As much as possible the dirt, excess cutting oils and standing water should be avoided or removed before the installation process is started [43]. Treating the water with biocide (selecting it with consideration of the type of MIC involved), to the water entering the restored system 
can slow the MIC process and extend the life of the piping.

When recirculating cooling water, cathodic inhibitors such as Azoles will be applied to avoid galvanic corrosion from steel by avoiding creation of copper deposits [36].

Almost all the components of the sprinkler and fire protection systems are metallic and so they are prone to corrosion one day or the other in the future. The utilization of chlorinated polyvinyl chloride (CPVC) or interlinking of polyethylene (PEX) is a concept that removes the metal from the triangle and removes also corrosion from the entire situation.. But there are limitations of these materials too but proper design and analysis before their installation can help with those limitations.

As the main cause of corrosion in steel pipes is oxygen, removal of oxygen can also be a very efficient way to reduce the process of corrosion. It can be done by two ways: 1 . Pumping an inert gas into the system (Ex. Nitrogen, as nitrogen gas doesn't react to any material) and completely removing the oxygen before filling the water pipes. Nitrogen pumps are available in the market. 2. Air Venting in wet pipe systems using the advanced vents available in the market. Both of them can be done by using a air vent and a pressurised nitrogen source as "Inert gas is supplied from the inert gas source to the pipe network. Water is supplied to the pipe network thereby substantially filling the pipe network with water and compressing the inert gas in the pipe network" [52].
In a wide variety of industries, chemical corrosion inhibitors are used to delay the corrosive deterioration of the metal components and structures. There are 2 types of chemical corrosion inhibitors as suggested by Jeffrey and Gerrard [53], organic and inorganic corrosion inhibitors. The go to options of alkyl amines and quaternary amines are not a good option for long piping system, although in freshwater environments they provide excellent control of corrosion, inorganic salt approach may work for such a system [53].

\subsection{Copper Pipes:}

Water should be separated from the copper tube before filling water to prevent corrosion in a pitting [44]. Careful ventilation of the tube would reduce pitting corrosion in the piping. The other options for remove air from the tube would be to purge the tubes with inert gas like nitrogen before filling them with water [44].

There are several chemical inhibitors available at the disposal of the fire sprinkler industry and the silicate and phosphate inhibitors are the most common. The silicate-based inhibitor has been proposed as the mild inhibitor for prevention of copper corrosion. The use of inorganic inhibitors as an alternative to organic compounds is based on the potential for time and temperature degradation of organic compounds. The study includes the following three different inorganic inhibitors: CrO42- chromate, MoO42-molybdate and B4O72- [54].

\section{Results and Discussions}

A lot of articles suggesting various types of coatings are listed below, with coating materials, coating methods and the results.

\begin{tabular}{|l|l|l|l|l|}
\hline No & Material & Method & Results & $\begin{array}{l}\text { Refere } \\
\text { nce }\end{array}$ \\
\hline 1 & Zinc-Silicate & Electrochemical deposition & $\begin{array}{l}20 \text { years of operation }-1 \text { failure } \\
\text { Hardness: 187 BHN reduced to } 163\end{array}$ & {$[55]$} \\
& $\begin{array}{l}\text { Primer } \\
160 \text { microns }\end{array}$ & & BHN & \\
\hline
\end{tabular}




\begin{tabular}{|c|c|c|c|c|}
\hline & $\begin{array}{l}\text { Epoxy } \\
\text { zinc-phosphate } \\
160 \text { microns } \\
\text { Acrylic } \\
\text { polyurethane } \\
120 \text { microns } \\
\text { Total } 440 \\
\text { microns }\end{array}$ & & $\begin{array}{l}\text { Foreign particles - } \mathrm{Cu}, \mathrm{Mn}, \mathrm{P}, \mathrm{S}, \mathrm{Ni} \text {, } \\
\mathrm{Al}, \mathrm{Ti}, \mathrm{V} \text { were found - came from fire } \\
\text { service water. } \\
\text { Localized corrosion - higher at } \\
\text { internal bottom surface - lower at } \\
\text { top internal surface. }\end{array}$ & \\
\hline 2 & $\begin{array}{l}\text { Polyaniline nano } \\
\text { particulate } \mathrm{TiO} 2 \\
\text { hybrid } \\
\text { composites } \\
\text { 15-17 microns }\end{array}$ & $\begin{array}{l}\text { Developed by in situ polymerizing } \\
\text { layer }\end{array}$ & $\begin{array}{l}\text { Exposure to hot saline conditions } \\
\text { Initially, the rate of corrosion } \\
\text { increases, but then tapers over 10-20 } \\
\text { hours. But a second region above } 30 \\
\text { hours again shows a strong increase } \\
\text { in the corrosion rate. }\end{array}$ & {$[56]$} \\
\hline 3 & $\begin{array}{l}\text { Nano-crystalline } \\
\text { Fe32-Ni36-Cr14- } \\
\text { P12-B6 }\end{array}$ & $\begin{array}{l}\text { Electro Sol-gel, chemical vapor } \\
\text { deposition (CVD) and physical vapor } \\
\text { deposition (PVD) can be modified } \\
\text { using feedstock powders having } \\
\text { Nano-grained structure } \\
\text { chemical deposition }\end{array}$ & $\begin{array}{l}\text { In specimen groups treated in } \\
\text { different conditions, the polarisation } \\
\text { resistances due to corrosion were } \\
\text { from } 153.4 \mathrm{k} / \text { to } / \mathrm{cm}^{2} \text { to } 635 \mathrm{k} / \text { to / } \\
\mathrm{cm}^{2} \text {. }\end{array}$ & {$[57]$} \\
\hline 4 & $\begin{array}{l}\text { Electroactive } \\
\text { polyimide-TiO2 } \\
\text { (EPTs) hybrid } \\
\text { film }\end{array}$ & Electrochemical deposition & $\begin{array}{l}\text { Corrosion rate }\left(\mathrm{R}_{\text {corr }}\right) \text { of ca. } 1.9 \times 10-3 \\
\mathrm{~mm} / \text { year }\end{array}$ & {$[58]$} \\
\hline 5 & $\begin{array}{l}\text { Aquence } 930- \\
\text { black gloss } \\
\text { coating } \\
15-28 \text { microns }\end{array}$ & $\begin{array}{l}\text { 5-7 minutes through flow }(9-18 \\
\mathrm{m} / \mathrm{min}) \\
4-8 \text { minutes through flow }(12-15 \\
\mathrm{m} / \mathrm{min}) \\
\text { Inwardly disposed coating }\end{array}$ & $\begin{array}{l}0.2 \mathrm{~mm}-1.2 \mathrm{~mm}(\mathrm{ID})-4-34 \% \text { better } \\
\text { Flow rate }\end{array}$ & {$[59]$} \\
\hline 6 & $\begin{array}{l}\text { UNSG10150 steel } \\
(\mathrm{Mn}=0.45 \%, \\
\mathrm{P}=0.010 \%, \\
\mathrm{~S}=0.031 \%, \\
\mathrm{C}=0.150 \% \text { \& } \\
\mathrm{Fe}=\text { balance }) \\
\text { Zn-Sn binary } \\
\text { powders } \\
90 \text { microns }\end{array}$ & $\begin{array}{l}\text { Rofin Sinar Nd: Yag Laser Processing } \\
\text { Unit }(750 \mathrm{~W}) \text { with a } 4.4-\mathrm{kW} \\
\text { continuous wave }(\mathrm{CW}) \text { laser } \\
\text { alloying. } \\
3 \mathrm{~mm} \text { diameter of beam, } 2.5 \mathrm{~g} / \mathrm{min} \\
\text { pound flow rate and } 0.6 \mathrm{~m} / \mathrm{min} \text { and } \\
0.8 \mathrm{~m} / \text { min scanning speeds. }\end{array}$ & $\begin{array}{l}\text { The experimental analysis shows a } \\
\text { huge amount } \\
19.9910 \mathrm{~mm} / \mathrm{yr} \text {. corrosion } \\
\text { deterioration at } 0.6 \mathrm{~m} / \mathrm{min}(\mathrm{Zn}: \\
\mathrm{Sn}=25: 75) \text { \& lowest corrosion } \\
\text { incidence }(0.0005 \mathrm{~mm} / \mathrm{yr} \text {.) at } 0.8 \\
\mathrm{m} / \mathrm{min}(\mathrm{Zn}: \mathrm{Sn}=25: 75) \text {. }\end{array}$ & {$[60]$} \\
\hline
\end{tabular}




\begin{tabular}{|c|c|c|c|c|}
\hline & thickness & & & \\
\hline 7 & $\begin{array}{l}\text { Mild steel pipe } \\
\text { Zn-ZnO-Y2O3 } \\
\text { Coating (Pure } \\
\text { Zinc plate anode, } \\
\text { Zinc Chloride, } \\
\text { Glycine, } \\
\text { Thiourea, Zinc } \\
\text { oxide (55nm, } 95 \\
\text { \%purity), } \\
\text { Yttrium oxide } \\
\text { (45nm, 98 } \\
\text { \%purity)) }\end{array}$ & $\begin{array}{l}\text { Electro-deposition using } 1 \mathrm{M} \mathrm{HCl} \\
\text { sol., static current electro-deposition } \\
\text { with } 0.5 \mathrm{~A} / \mathrm{cm} \text { sq. used for } \\
\text { deposition. }\end{array}$ & $\begin{array}{l}\text { Corrosion potential and current } \\
\text { density of the mild steel and the mild } \\
\text { steel with coating were observed to } \\
\text { be improved from }-1.547 \mathrm{~V} \text { to }-1.341 \mathrm{~V} \\
\text { and } 12.404 \text { to } 1.802 \mathrm{~mA} / \mathrm{cm} \text { sq. } \\
\text { respectively. }\end{array}$ & {$[61]$} \\
\hline 8 & $\begin{array}{l}\text { A356 mild steel } \\
\text { pipe and } \\
\text { Zn-CeO2 (14 } \\
\text { microns) and } \mathrm{Zn-} \\
\mathrm{CeO} 2-\mathrm{Al} 2 \mathrm{SiO} 5 \\
\text { (17 microns) } \\
\text { coatings }\end{array}$ & $\begin{array}{l}\text { The coating developed for electro- } \\
\text { deposition was achieved in } 2 \mathrm{~V} \text { for } \\
10 \text { min with a constant current } \\
\text { density of } 1.5 \mathrm{~A} / \mathrm{cm} 2 \text { and } 4.5 \mathrm{pH}\end{array}$ & $\begin{array}{l}\text { The } \mathrm{Zn}-10 \mathrm{CeO} 2-5 \mathrm{Al} 2 \mathrm{SiO} 5 \text { coated } \\
\text { sample corrosion rate was the least } \\
\text { with } 0.0171 \text { (mm / yr.) corrosion rate. }\end{array}$ & {$[62]$} \\
\hline 9 & $\begin{array}{l}\text { UNS G10150 } \\
\text { Steel } \\
\text { Zn-Sn binary } \\
\text { powders }\end{array}$ & $\begin{array}{l}\text { Laser alloy coating with a } \\
\text { continuous wave }(\mathrm{CW}) \text { of } 4.4 \mathrm{KW} \\
\text { Rofin Sinar Nd: laser processing } \\
\text { system YAG and } 700 \mathrm{~W}, 4 \mathrm{~mm} \text { beam } \\
\text { diameter, } 3 \mathrm{~g} / \text { min powder flow rate } \\
\text { and } 0.6 \mathrm{~m} / \mathrm{min} \text { scanning speed. } \\
\text { As for } 0.8 \mathrm{~m} / \mathrm{min} \text {. }\end{array}$ & $\begin{array}{l}\text { Section of the surface }(25 \mathrm{Zn}: 75 \mathrm{Sn}) \text { on } \\
\text { a } \\
\text { Scanning speed of } 0.8 \mathrm{~m} / \mathrm{min} \\
\text { produces the best performance } \\
\text { against corrosion with the lowest } \\
\text { current density ( } 7.95 X 10-8 \mathrm{~A} / \mathrm{cm} 2) \text {, } \\
\text { the lowest corrosion rate } \\
\text { (0.000924 mm / year) and optimum } \\
\text { tolerance to polarization Rp } \\
\text { (3163000). }\end{array}$ & {$[63]$} \\
\hline 10 & $\begin{array}{l}\text { Mild steel pipe }= \\
13 m m \text { diameter } \\
\text { Benzamide } \\
\text { Coating }\end{array}$ & $\begin{array}{l}\text { The samples were fully submerged } \\
\text { in solutions where amounts of } \\
\text { benzamide inhibitors used were: } 1 \text {, } \\
2,3 \text {, and } 4 \mathrm{~g} 200 \mathrm{~mL}-1 \mathrm{H} 2 \mathrm{SO} 4 \text {, } \\
\text { respectively. }\end{array}$ & $\begin{array}{l}\text { Corrosion rate }(\mathrm{mm} / \text { year) for the four } \\
\text { samples of steel with different } \\
\text { concentrations of Benzamide }(1 \mathrm{~g}, 2 \mathrm{~g} \text {, } \\
3 \mathrm{~g} \& 4 \mathrm{~g}) \text { were } 1.42 \mathrm{E}+01,1.35 \mathrm{E}+01 \text {, } \\
1.26 \mathrm{E}+01 \text { and } 7.48 \mathrm{E}+00 \text { respectively. }\end{array}$ & {$[64]$} \\
\hline 11 & $\begin{array}{l}\text { Mild steel } \\
\text { Zn-ZnO-Ant hill } \\
\text { particulate } \\
\text { composite }\end{array}$ & Co-deposition for 20 mins & $\begin{array}{l}\text { Corrosion rate: } 0.331 \text { MPY, } 0.2377 \\
\text { MPY, } 0.01863 \text { MPY for low carbon } \\
\text { steel, without and with orange juice } \\
\text { respectively }\end{array}$ & {$[65]$} \\
\hline
\end{tabular}




\begin{tabular}{|c|c|c|c|c|}
\hline & $\begin{array}{l}\text { coating \& } 10 \mathrm{ml} \\
\text { Orange juice } \\
\text { (133 microns) }\end{array}$ & & & \\
\hline 12 & $\begin{array}{l}\mathrm{Zn}-20 \mathrm{~V}_{2} \mathrm{O}_{5} \\
\mathrm{Zn}-20 \mathrm{~V}_{2} \mathrm{O}_{5-} \\
6 \mathrm{NbO}_{2} \\
\mathrm{Zn}-20 \mathrm{~V}_{2} \mathrm{O}_{5-} \\
12 \mathrm{NbO}_{2}\end{array}$ & $\begin{array}{l}\text { Electrolytic bath with activating } \\
\text { solution } \\
\text { The deposition was formulated using } \\
\text { sulphate-based constituent with } 0.5 \\
\text { M H2SO } 4 \text { triggering solution. The } \\
\text { deposition taken with pH of } 4 \text { for } 15 \\
\text { s }\end{array}$ & $\begin{array}{l}\text { Corrosion rate }(\mathrm{mm} / \text { year }) \\
\text { Sample } 1=0.315 \\
\text { Sample } 2=0.932 \\
\text { Sample } 3=1.128 \\
\text { And for substrate } 4.1 \mathrm{~mm} / \text { year }\end{array}$ & {$[66]$} \\
\hline 13 & $\begin{array}{l}\text { nanocrystalline } \\
\text { zinc coating - } 40 \\
\text { microns }\end{array}$ & $\begin{array}{l}\text { Electrodeposited onto the steel } \\
\text { substrate using a polyacrylamide } \\
\text { sulfate bath as a grain refiner }\end{array}$ & $\begin{array}{l}\text { The corrosive wear resistance of the } \\
\text { zinc coating was almost } 39 \text { times } \\
\text { increased as the grain size was } \\
\text { reduced from } 5 \mu \mathrm{m} \text { to } 40 \mathrm{~nm}\end{array}$ & {$[67]$} \\
\hline 14 & $\begin{array}{l}\text { Nanocrystalline } \\
\text { zinc coating } \\
\text { Avg. } 30-60 \\
\text { microns }\end{array}$ & $\begin{array}{l}\text { Made from zinc coatings with } \\
\text { galvanostatic electrodeposition on } \\
\text { carbon steel substrate simple sulfate } \\
\text { bath with polyacrylamide, } \\
\text { acrylamide, furamide, acrylic acid } \\
\text { and, as an additive, polyacrylic acid. }\end{array}$ & $\begin{array}{l}\text { The wear rate and corrosion } \\
\text { incidence of nano-crystalline zinc } \\
\text { coating in } \mathrm{Na}-\mathrm{Cl} \text { and } \mathrm{Na}-\mathrm{OH} \\
\text { corrosion media are found to be } \\
\text { around } 96 \text { percent lower and less } \\
\text { than } 1 / 2 \text { of that of coarse-grained } \\
\text { zinc coating }\end{array}$ & {$[68]$} \\
\hline 15 & $\begin{array}{l}\text { Nanocrystalline } \\
\text { zinc coating } \\
56 \text { microns }\end{array}$ & $\begin{array}{l}\text { Nanocrystalline zinc coatings are } \\
\text { electrodeposited in a sulfate bath } \\
\text { with polyacrylamide as the only } \\
\text { additive by direct current (DC), } \\
\text { pulse current (PC) and pulse reverse } \\
\text { current (PRC) techniques }\end{array}$ & $\begin{array}{l}\text { The overall wear intensity of the } \\
\text { nanocrystalline zinc coating is } \\
\text { around } 1 / 24 \text { that of the coarse- } \\
\text { grained zinc under the same wear } \\
\text { and friction conditions }\end{array}$ & {$[69]$} \\
\hline 16 & $\begin{array}{l}\text { Nanocrystalline } \\
\text { zinc coating } \\
6 \text { microns }\end{array}$ & $\begin{array}{l}\text { Pulse reverse electro-deposition in a } \\
\text { polyacrylamide sulfate bath as the } \\
\text { main addition }\end{array}$ & $\begin{array}{l}\text { Upgraded erosion resistance in the } \\
\text { reenacted seawater compared to } \\
\text { coarse-grained zinc coating, since } \\
\text { nano-crystalline zinc coating is } \\
\text { characterized by a high-volume } \\
\text { division of grain boundary with the } \\
\text { diminishment of grain sizes from } \\
\text { small scale }(6 \mu \mathrm{m}) \text { to nano scales ( } 31 \\
\mathrm{~nm})\end{array}$ & {$[70]$} \\
\hline 17 & $\begin{array}{l}\text { Nano Composite } \\
\mathrm{Zn}-\mathrm{ZnO}-\mathrm{Mg} \\
\text { coating ( } 420 \\
\text { microns) on Mild } \\
\text { steel substrate }\end{array}$ & $\begin{array}{l}\text { Electrodeposition with } 3 \mathrm{~V} \text { for } 20 \\
\text { mins in } 2 \mathrm{M} \mathrm{HCl} \text { solution }\end{array}$ & Corrosion rate $146.93 \mathrm{~mm} /$ year & {$[71]$} \\
\hline 18 & Reinforced Zn- & Electrodeposition at $3 \mathrm{~V}$ for 20 & Corrosion rates: $0.2455,0.1021$, & {$[72]$} \\
\hline
\end{tabular}




\begin{tabular}{|c|c|c|c|c|}
\hline & $\begin{array}{l}\mathrm{TiO}_{2} / \mathrm{ZnTiB}{ }_{2} \text { and } \\
\mathrm{Zn}-\mathrm{TiO}_{2-} \\
\text { Solanum coating } \\
\text { on mild steel }\end{array}$ & minutes in $1 \mathrm{~mol} \mathrm{HCl}$ solution & $1.1222 \mathrm{~mm} /$ year respectively & \\
\hline 19 & $\begin{array}{l}\text { Silane- } \\
\text { functionalized } \\
\text { bisphenol-F- } \\
\text { based } \\
\text { benzoxazine } \\
\text { (SBz) for Mild } \\
\text { Steel }\end{array}$ & $\begin{array}{l}\text { Spin-coated ( } 1000 \mathrm{RPM}) \text { with } \\
\text { monomer arrangement and dried in } \\
\text { vacuum at } 100{ }^{\circ} \mathrm{C} \text { for } 1 \mathrm{~h} \text { to expel the } \\
\text { remaining solvents. Arranged metal } \\
\text { substrates were cured at } 230^{\circ} \mathrm{C} \text { for } 2- \\
3 \mathrm{~h} \text { to urge the } \mathrm{SPBz} \text { coated metal } \\
\text { substrates. }\end{array}$ & $6.93 \times 10-{ }^{09} \mathrm{MPY}$ & {$[73]$} \\
\hline
\end{tabular}

Conventional surface modifications and coatings cannot fulfill the efficiency of material surface under wear and corrosion environments in wet style sprinkler systems [74]. Hence, an alternate technique for enhanced surface properties is desired.

To improve the corrosion performance of zinc-coated steel pipes and to reduce costs, a lot of investment is made in optimizing the composition of zinc-coating by alloying. In the present situation, hot dip $\mathrm{Zn}-\mathrm{Al}-$ $\mathrm{Mg}$ coated steel components join the industry for building and automobile applications, and physical vapor deposition (PVD) coatings are under production [75].

Anieszka and team figured that the $\mathrm{Zn}-\mathrm{Ni}$ surface layer coatings have a stronger tolerance to corrosion than the Zn-Co surface layer coatings [76].

The inert gas reaches the water delivery network at least one entry level, which significantly prohibits ambient air which oxygen from entering the water distribution system [77].

Although inert particles in a reactive gas flow can remove flames by cooling, reactive molecules create inert gases that dilute the concentrations of fuel or oxidizer locally and thus suppress the flames [78].

\section{CONCLUSION}

There are multiple reasons which lead to the formation of rust in the metal pipes of fire sprinkler systems such as oxygen-water reaction, microorganisms, erosion, etc but it is clear that the most important of them is oxygen-water reaction which occurs due to the air in the system. The above study suggests several prevention and mitigation methods to limit and avoid the phenomenon of corrosion in the piping and number of options of coating materials for the same. It is observed that Zinc is the most common material used in a lot of these coatings, which clearly indicates that there is a possibility of improving the conventional Zinc coating even more, with the use of other materials, which can be found out with further studies and experiments.

\section{REFERENCES}

[1]. NFPA Fire protection handbook (pg 2-19)

[2]. Influence of Potassium Nitrate on the Combustion Rate of a Water-based Aerosol Fire Extinguishing Agent - Zhou Xiaomeng* and Liao Guangxuan (2004)

[3]. Enhanced dry chemical fire extinguishing composition, apparatus, and method - Gerald Flood (2017)

[4]. Foam fire suppressant system - Kieth Olson (2019) 
[5]. In-rack fire protection sprinkler system Thomas Multer \& Oliver Pahila (2019)

[6]. Automatic Fire Sprinkler Systems: An Overview of Past Seismic Performance, Design Standards \& Scope for Future Research - M. Rashid, R. P. Dhakal \& T. Z. Yeow Department of Civil Engineering, University of Canterbury, Christchurch(2018)

[7]. Piping layout for fire sprinkler system: An overview - Kshitiz Vishnoi (2017)

[8]. Bayes Networks and Fault Tree Analysis application in Reliability Estimation (Case Study: Automatic Water Sprinkler System) Saeed Givehchi, Alireza Heidari School of Environment, College of Engineering, University of Tehran, Tehran, Iran (17 July 2018)

[9]. Fire Inhibitor formulation - Mark Vuozzo , San Diego, CA ( US ) - 2018

[10]. Corrosion Prevention and Protection: Practical Solutions V. S. Sastri, E. Ghali and M. Elboujdaini (2007) John Wiley \& Sons, Ltd

[11]. Fire Protection (Detection, Notification, and Suppression) Second Edition - Robert C. Till John Jay College of Criminal Justice New York, NY, USA \& J. Walter Coon Overland Park Kansas, USA - 2019

[12]. Electrically operated gas vents for fire protection sprinkler systems and related methods - Jeffrey T. Kochelek, Creve Coeur, $\mathrm{MO}(\mathrm{US})$; Adam H. Hilton, Chesterfield, MO (US); Lucas E. Kirn, Saint Louis, MO (US); Matthew J. Kochelek, Chesterfield, MO (US) (2018)

[13]. Belleville seal for valve seat having a tear drop laminar flow feature - Thomas Edwin; (Midland, MI); RINGER; Yoram; (Providence, RI) ; MEYER; Stephen J.; (Chester Springs, PA) (August 2019)

[14]. Preaction sprinkler valve assemblies, related dry sprinkler devices and fire protection sprinkler systems - Stephen J. MEYER, Chester Springs, PA (US); Yoram RINGER, Providence,
RI (US); Thomas Edwin ARCHIBALD, Midland, MI (US) - (2018)

[15]. Flexible drain - pipe conduit for fire suppression sprinkler system - Stephen J. MEYER, Chester Springs, PA (US); Ralph WATSON, Newnan, GA (US); Stewart YOUNG, Lake Geneva, WI (US) (2019)

[16]. Sprinkler system with a pre-action sprinkler head - David Ryan GroenRandal John Bird (2018)

[17]. Devices, methods and systems for monitoring water-based fire sprinkler systems - Jeffrey $\mathrm{T}$. KOCHELEK, Creve Coeur, MO (US); Adam H. HILTON, Chesterfield, MO (US) (2017)

[18]. System and methods for wet system fire protection - Zachary L. Magnone, Jeremiah $\mathrm{P}$ Crocker, John Desrosier, Sean E. CuttingManuel R. Silva (2017)

[19]. Corrosion monitoring in fire sprinkler system Jeffrey T. Kochelek, Creve Coeur, MO (US); Adam H. Hilton, Chesterfield, MO (US); Lucas E. Kirn, St. Louis, MO (US) (2015)

[20]. Antifreeze sprinkler system - Michael J. Bosma (2018)

[21]. Wet pipe fire protection sprinkler system dual air vent with water retention and return - Scott Christian Bodemann \& Timothy S. Bodemann (2018)

[22]. Dry sprinkler assembly - Scott T. FransonAndrew T. Thompson (2017)

[23]. Enhanced corrosion resistant channels, fittings and fasteners -Timothy R. Oliver, Cedar Lake, IN (US); Jacob R. Shaw, Chicago, IL (US); Darin Gleason, Green Oaks, IL (US)

[24]. Copper Corrosion and Biocorrosion Events in Premise Plumbing Ignacio T. Vargas 1,2 ID, Diego A. Fischer 1, Marco A. Alsina 1, Juan P. Pavissich 3 ID, Pablo A. Pastén1,2 and Gonzalo E. Pizarro 1,2

[25]. Standpipe systems for fire protection - Kenneth E. Isman (2017)

[26]. Microbiologically Influenced Corrosion (MIC) IS NOT the Primary Cause of Corrosion in Fire 
Sprinkler Systems (October 2009) By Jeffrey T. Kochelek

[27]. The Effect of Corrosion Inhibitor on Corrosion Control of Copper Pipe and Green Water Problem Ji Eun Lee, Hyun Dong Lee, Gi Eun Kim School of Chemical and Biomolecular Engineering, University of Sydney, NSW 2006, Australia.

[28]. Volkan Cicek, Corrosion Engineering, Scrivener Publishing Wiley, MA, 2014.

[29]. Current Recommendations Regarding the Use of Galvanized Steel Sprinkler Piping within the Fire Protection Industry in Sprinkler Age Magazine (September/October 2018 issue)

[30]. Corrosion Control Inside Water-filled Steel Fire Sprinkler Piping - Bruce W. Christ - 2015

[31]. Rieger, P.H., "Corrosion - Reaction of a Metal with Air-Saturated Water," In: Chapter 7 in Electrochemistry, Second Edition, Chapman and Hall, New York, 1994, p. 416.

[32]. National Fire Codes, NFPA 13, Standard for the Installation of Sprinkler Systems, 1996 Edition, National Fire Protection Association, Batterymarch Park, Quincy, MA 02269. a. Subparagraph 13:2-3, Table 2-3.1, "Pipe or Tube Materials and Dimensions," pp. 13-12. b. Paragraph 13:4-14.4.2, "Protection of Piping against Corrosion," pp. 13-55. c. Sub-paragraph 13:4-14.4.2.2, "Protection of Piping against Corrosion," pp. 13-55.

[33]. Corrosion and sludge prevention in Automatic sprinkler - Fire protection system - Roger K. Talley - 1996

[34]. Microbiologically Influenced Corrosion of a Pipeline in a Petrochemical Plant - Mahdi Kiani Khouzani 1 , Abbas Bahrami 1 , Afrouzossadat Hosseini-Abari 2 , Meysam Khandouzi 1 and Peyman Taheri 3 36Pope, D. H., Duquette, D. J., Johannes, A. H., and Wayner, P. C., "Microbiologically Influenced Corrosion of Industrial Alloys," Materials Performance, July 1984
[35]. El Hajj, H.; Abdelouas, A.; El Mendili, Y.; Karakurt, G.; Grambow, B.; Martin, C. Corrosion of carbon steel under sequential aerobic-anaerobic environmental conditions. Corros. Sci. 2013, 76, 432-440.

[36]. R. Sooknah, S. Papavinasam, R.W. Revie, Monitoring Microbiologically Influenced Corrosion: A Review of Techniques, CORROSION/2007, Paper No. 07517. (Houston, TX: NACE 2007).

[37]. B.I. Beech, C.C. Gaylarde, Recent advances in the study of biocorrosion: an overview, Revista de microbilogia 30 (1999) 177-190.

[38]. A.H. Kaksonen, S. Spring, P. Schumann, R.M. Kroppenstedt, J.A. Puhakka, Desulfotomaculum thermosubterraneum sp. nov a thermophilic sulphatereducer isolated from an underground mine located in a geothermally active area, Int. J. Syst. Evol. Microbiol. 56 (2006) 2603-2608.

[39]. The effect of a sulphate-reducing bacteria on the rate of corrosion of steel alloys by Shaku, G. Danha, N. Hlabangana, S. Bhero

[40]. Microbiologically Influenced Corrosion in Fire Sprinkler Systems - Bruce H. Clarke Anthony M. Aguilera - 2007

[41]. Bsharat, T.K., "Detection, Treatment and Prevention of Microbiologically Influenced Corrosion in Water-Based Fire Protection Systems," Technical Report of the National Fire Sprinkler Association, Inc, 4 Robin Hill Corporate Park, Patterson, New York, June 1998, 16 pp. a. Basic Corrosion, Figure 1 illustrates carbon steel being oxidized into its ionic state, p. 4. b. Appendix A - Examples of Biocides: Chlorine, Iodine, Hydrogen Peroxide, Ozone, p. 12.

[42]. Analysis of pitting corrosion failure of copper tubes in an apartment fire sprinkler system Sang Hee Suh, Youngjoon Suh, Hyung Goog Yoon, Jeong Han Oh, Youngjun Kim, KiMin Jung, HyukSang Kwon - 2016

[43]. T. H. Merkel \& S. O. Pehkonen (2006) General corrosion of copper in domestic drinking water 
installations: scientific background and mechanistic understanding, Corrosion Engineering, Science and Technology, 41:1, 2137, DOI: $10.1179 / 174327806$ X94009

[44]. Dou W, Jia R, Jin P, Liu J, Chen S, Gu T, Investigation of the mechanism and characteristics of copper corrosion by sulfate reducing bacteria, Corrosion Science (2018), https://doi.org/10.1016/j.corsci.2018.08.055

[45]. G. P. Marsh, I. D. Bland, and K. J. Tayloret, "Statistical study of pit propagation in carbon steel under nuclear waste disposal condition," British Corrosioin Journal, vol. 23, no. 3, pp. 157-164, 1988.

[46]. Jin-A Jeong, Chung-Kuk Jin, Jin Uk Lee "A study on the corrosion evaluation and lifetime prediction of fire extinguishing pipeline in residential buildings" in Journal of the Korean Society of Marine Engineering, Vol. 39, No. 8 pp. 828 832, 2015

[47]. Pitting corrosion of copper in waters with high $\mathrm{pH}$ and low alkalinity - Darren A Lytle and Michael R. Schock - 2008

[48]. Localized pitting corrosion of API 5L grade A pipe used in industrial fire water piping applications - Chidambaram Subramanian Numaligarh Refinery Limited, Assam, India 2018

[49]. A multifunctional super-hydrophobic coating based on PDA modified MoS2 with anticorrosion and wear resistance - Xiaoying Zhanga, Huaiyuan Wanga,b, Xiguang Zhangb, Zhiqiang Zhaoa, Yanji Zhua - 2019

[50]. High nitrogen and other inert gas anticorrosion protection in wet fire protection system - Jeffrey T. Kocchelek - 2014

[51]. Controlling Corrosion in Wet Pipe Fire Sprinkler Systems Using Chemical Corrosion Inhibitors (March 2011) By Jeffrey T. Kochelek and Gerard. J. van Moorsel

[52]. Copper Corrosion Inhibitors. A review - M. M. Antonijevic* and M. B. Petrovic -University of
Belgrade, Technical Faculty Serbia 20 November 2007

[53]. Localized pitting corrosion of API 5L Grade A pipe used in industrial fire water piping applications - (2018)

[54]. Conducting polyaniline-nano-TiO2 composites for smart corrosion resistant coatings -2017

[55]. Effect of nanostructure on corrosion and corrosion resistance of materials - A.A.ElMeligi, L.I.Palatino (2014)

[56]. Advanced anticorrosive coatings prepared from electroactive polyimide-TiO2 hybrid nanocomposite materials -2016

[57]. Fire extinguishing systems - September 2019

[58]. Characterization and Corrosion Behavior of ZnSn Binary Alloy Coatings in $0.5 \mathrm{M} \mathrm{H} 2 \mathrm{SO} 4$ Solution - 2015

[59]. Anti-corrosion coating of mild steel using ternary $\mathrm{Zn}-\mathrm{ZnO}-\mathrm{Y} 2 \mathrm{O} 3$ by electro-deposition (2016)

[60]. Mechanical and opto-electrical response of embedded smart composite coating produced via electrodeposition technique for embedded system in defense application (2019)

[61]. Electrochemical Studies on the Corrosion Behavior of Laser Alloyed Zn-Sn Coatings on UNS G10150 Steel in 1M HCl Solution (2015)

[62]. Effect of Benzamide on the Corrosion Inhibition of Mild Steel in Sulfuric Acid (2017)

[63]. Surface modification of mild steel by codeposition using $\mathrm{Zn}-\mathrm{ZnO}$-Ant hill particulate composite coating in simulated sea water- July 2018

[64]. Electrolytic deposition of super-smart composite coating of $\mathrm{Zn}-\mathrm{V} 2 \mathrm{O} 5-\mathrm{NbO} 2$ on low carbon steel for defense application - O.S.I. Fayomi, L.R. Kanyane, A.P.I. Popoola, S.O. Oyedepo (2018)

[65]. Electrodeposition of nanocrystalline zinc on steel for enhanced resistance to corrosive wear Qingyang Li, Hao Lu, Juan Cui, Maozhong An, Dongyang Li (2016) 
[66]. Insight into the Role and Its Mechanism of Polyacrylamide as an Additive in Sulfate Electrolytes for Nanocrystalline Zinc Electrodeposition - Qingyang Li, Wang Ge, Peixia Yang, Jinqiu Zhang, and Maozhong An (2016)

[67]. Research on the tribological behavior of nanocrystalline zinc coating prepared by pulse reverse electrodeposition - Qingyang Li, Zhongbao Feng, Lihua Liu, Jie Sun, Yunteng $\mathrm{Qu}$, Fenghuan Lia and Maozhong An (2012)

[68]. Deciphering the formation mechanism of protective corrosion product layer from electrochemical and natural corrosion behaviors of nanocrystalline zinc coating Qingyang Li, Zhongbao Feng, Lihua Liu, Hong $\mathrm{Xu}$, Wang Ge, Fenghuan Lia and Maozhong An (2012)

[69]. Influence of composite Nano Coating on Ternary Sulphate Co-deposition: Corrosion and Surface characterization - P.A.L. Anawe, O. Raji, O.S.I. Fayomi, V.E. Efeovbohkan (2017)

[70]. Development of reinforced in-situ anticorrosion and wear $\mathrm{Zn}-\mathrm{TiO} / \mathrm{ZnTiB2}$ coatings on mild steel - O.S.I. Fayomi, A.P.I. Popoola, L.R. Kanyane, T. Monyai (2017)

[71]. Silane-functionalized polybenzoxazines: A superior corrosion resistant coating for steel plates - S. Krishnan, H. Anandarup, C. Kuppan, A. Goswami M. Chavali, A. Muthukaruppan (2017)

[72]. Influence of Rapid Solidification on the Thermophysical and Fatigue Properties of Laser Additive Manufactured Ti-6Al-4V Alloy Olawale Samuel Fatoba, Esther Titilayo Akinlabi and Mamookho Elizabeth Makhatha (2017)

[73]. Coil-coated $\mathrm{Zn}-\mathrm{Mg}$ and $\mathrm{Zn}-\mathrm{Al}-\mathrm{Mg}$ : Effect of climatic parameters onthe corrosion at cut edgesTomas Prosek*, Andrej Nazarov, Anne Le Gac, Dominique Thierry (2015)

[74]. Galvanic formation of $\mathrm{Zn}-\mathrm{Ni} / \mathrm{Zn}-\mathrm{Co}$ type multilayer alloy coatings on steel substrate -
Agnieszka Nagrabia, Maciej Sowa, Wojciech Simka and Artur Maciej (2015)

[75]. Inhibiting oxygen corrosion in water supply systems, piping networks and water-based fire sprinkler systems - Jeffrey T. Kochelek, Creve Coeur MO (US) (2019)

[76]. Suppression of premixed flames with inert particles - Sreenivasan Ranganathan, Minkyu Lee, V'yacheslav Akkerman, Ali S. Rangwala (2015)

\section{Cite this article as :}

Sh A 